\title{
THE MAIN ASPECTS OF INNOVATIVE DEVELOPMENT REGIONS OF THE REPUBLIC OF UZBEKISTAN
}

\author{
Otajanov Umid Abdullaevich \\ Department of "Econometrics", Tashkent State University of Economics, \\ uotajanov@bk.ru
}

\begin{abstract}
The article considers the main problems of the development of innovative activities of the regions of Uzbekistan, focuses on the policy of the government of the republic on this issue, and suggests measures to further solve them, shows the possibility of using neural network technologies in modeling regional development based on classical statistical and econometric methods.
\end{abstract}

Keywords: innovation, innovation, investment, investors, information and communication technologies, infrastructure, competitiveness, modeling, forecasting, neural networks, neural network technologies.

\section{Introduction}

The development of the innovation sphere, the intensification of innovation activities are an important priority for the development of Uzbekistan in the coming decades. The globalization of the world economy, the intensification of competition in the main markets of advanced technologies require from domestic enterprises a radical modernization of the existing production system and the transition to new technologies.

The Government of the Republic of Uzbekistan pays great attention to these issues.

Support for innovative investment activities should be carried out by the state. Annex No. 1 to the Decree of the President of the Republic of Uzbekistan of February 7, 2017 No. UP-4947 states that it is necessary: "to pursue an active investment policy aimed at upgrading, technical and technological renewal of production, implementation of industrial, transport and communication and social infrastructure projects" (2017). In addition, it is necessary to "comprehensive and balanced socio-economic development of regions, districts and cities, actively attracting foreign investment in sectors of the economy and regions of the country by improving the investment climate" (2017).

The strategy of action in the five priority areas of development of the Republic of Uzbekistan in 2017-2021 provides for "improving the investment climate, actively attracting foreign, primarily foreign direct investment, into sectors of the economy and regions of the country" (2017).

The various government documents identify the main areas of investment policy of the republic, providing for a set of measures to strengthen the positive growth trends of investments, to attract investment resources to the republic, to increase their efficiency, which contributes to the creation of a highly efficient economic base and a developed social sphere that ensures a high standard of living.

Of all the republics of Central Asia, Uzbekistan is the leader in both investment potential and investment risk. The fundamental task of developing investment processes in the republic is to create a favorable investment climate for attracting domestic and foreign investments. 


\section{Literature review}

In the scientific literature (Atoyan V.R., 2006), questions of the feasibility of the formation of the innovation potential in economic systems of various levels of complexity are considered in relation to the opportunities of the educational, scientific and innovative sphere, the level of development of which largely determines its size and the degree of its involvement in the real economy. Today we are talking about the innovation infrastructure as a combination of various enterprises and organizations, which, on the one hand, provide the scientific and technical development of the region, and on the other hand, implement the planned indicators in the practical field.

One of the important issues in the complex socio-economic development of the region is the formation of its innovative environment, and therefore, it is necessary to form an innovative development strategy not only at the regional level, but also at the local levels (Guriev L.K., 2003). The development of the region on the basis of innovation is the most important factor in its competitiveness. M. Porter considers the innovative potential and innovativeness of the regional economy as the most important competitive advantage. In a broader sense, the competitiveness of a region can be represented as a set of stable relations in the field of socio-economic development of the region in cooperation with other regions, which allow creating new combinations of products, industries and spheres of economic activity. These combinations, in turn, are aimed at the formation and promotion of innovative products and new activities for the region, thus ensuring its innovative leadership and competitiveness.

Innovation activity is traditionally associated with a high level of risk: according to statistics, only $10 \%$ of all implemented developments have commercial success (Gorbachev A.V.\&Starostin A.A., 2004).

Therefore, first of all, at the level of regional and municipal authorities, it is necessary to create and maintain a system for managing the commercialization of $R \& D$ products, oriented to work in market conditions. Such a system will allow uncovering and stimulating the development of the potential of Russian scientific organizations and at the same time contribute to bringing the economy to a qualitatively new level.

At the micro level, innovation activity is carried out through appropriate innovative projects. An innovative project is a complex system of interdependent and interconnected resources, deadlines and implementers of activities aimed at achieving specific goals in priority areas of science and technology (Gorbachev A.V.\&Starostin A.A., 2004).

\section{Main part}

Innovative development of any region is its ability to self-renew, adapt to changes and generate products of scientific and technological progress. World experience shows that the sustainable development of production and maintaining its competitiveness in the long term depends not only on resource capabilities, but more on innovation.

When forming a model of a national innovation system, immanent problems arise in developing the conceptual foundations of the innovation strategy of regions. It is proposed to consider the tasks, conditions, levers and mechanisms, consideration of which is necessary when developing a regional model of innovative development (Guriev L.K., 2003).

One of the important issues in the complex socio-economic development of the region is the formation of its innovative environment, and therefore, it is necessary to form an innovative development strategy not only at the regional level, but also at the local levels. Regional development based on innovation is the most important factor for its competitiveness.

Among the objectives of the region, which determine the features of strategic management of innovations, we can highlight the expanded reproduction of regional intellectual resources, the development of regional innovation infrastructure and the creation of favorable conditions for innovation activities. 
First of all, this impact is through the personnel component and the education system. The developed university and scientific sector of the region serves as the most important intellectual prerequisite for raising the level of innovative potential.

The modern economy is characterized by dynamism and instability of the processes occurring in the market. The economy of the transformation period, both in Uzbekistan and other countries that have taken the path of market transformation, is characterized by a high level of instability associated with the constant change not only in volume, but also in the direction of development. The effectiveness of the functioning of both the national economic system and its regions depends on how effectively the innovative transformations are carried out. An important aspect of the innovation development of the regions is the identification and elimination of problems that hinder the pace of this development.

The distribution of investments by industry in the republic in recent years shows the minimum amount of investment in the information sector. However, information and communication technologies are becoming increasingly important for the formation of information resources and their use in the management of the socio-economic development of the country. Currently, a regulatory framework is being created, information technologies are being introduced in all spheres of public life and the economy. Information and communication technologies have a huge impact on almost all aspects of life.

The main problems of informatization development in the republic include: territorial extent, insufficient development of information and communication resources, lack of trained personnel and a number of other reasons.

For the accelerated development of the information sector in the region, there are such obstacles as:

$>$ a formalized approach to the problem of informatization of the regional economy and the creation of an innovative sector of the economy;

$>$ lack of personnel in the field of information systems and technologies at the modern level;

$>$ insufficient funding from the state;

$>$ Insufficient capital inflows to business and a number of others.

The solution of these problems in the economy of the republic and the creation of conditions for the formation of the information society presupposes an active state policy with respect to the information sector of the economy, which includes, first of all, the investment policy. In this regard, it became necessary to develop an investment strategy. The main thing, in our opinion, is an integrated approach to the consideration of specific territorial forms of location of the information sector.

As world experience shows, the most dynamic development is received by those regions where a regional innovation infrastructure is being formed, which covers educational and scientific institutions, enterprises, research centers, government bodies, financial institutions. Thus, to ensure the innovation development of the regions, it is necessary to formulate and legally fix the state policy of regional development, coordinate the development of specific regions taking into account the priority directions of innovation activity, as well as implement measures for the formation of a regional innovation infrastructure.

In general, an infrastructure is a system that can consist of the following subsystems:

$>$ scientific, technical and innovation subsystem, providing scientific support of management processes;

$>$ investment and financial institutions, including enterprises of the venture industry;

$>$ business enterprises and organizations;

$>$ information network; 
$>$ Specialized innovation structures (business parks and business incubators, innovation centers, etc.);

$>$ sphere of investment and innovative services;

$>$ specialized funds (Osaulenko A.I., 2003).

For short-term forecasting of foreign investment in the region's economy and their further optimal distribution by economic activity in order to provide an additional maximum gross regional product, it is necessary to use a set of mathematical models of neural network modeling and dynamic programming.

In strategic management among the methods of forecasting the development of regions, the program-target method, the balance method, the methods of expert estimates, extrapolation, econometric modeling, the normative method are widely used. However, in solving the problems of regional forecasting and modeling, scientific and technical advances created by the development of information technologies and based on the use of artificial neural networks (INS) are poorly used. Neural networks give the best results in comparison with other methods precisely when connections in the system are difficult to trace and cannot be analyzed, their number is too large in volume.

Based on the study of the main strategic documents for the development of branches of the regional level of the republic, it is necessary to form a system of indicators that comprehensively characterize the current state of the branches of the national economy. In general, the information base should be organized in accordance with the basic requirement for the information system of macroeconomic forecasting - it is necessary to cover and reflect all branches of the territory's economy in terms of the minimum number of aggregates, and describe the structure of the economic, social and financial complexes of the region.

For the training of the neural network, you can use the quasi-Newtonian algorithm BFGS. In Statistica 10.0 there is a hardware implementation of this algorithm, so the calculation can be made in its statistical package Neural Networks (Neural networks, 2000). The scheme of neural network modeling of regional development is shown in Figure 1. 




Fig. 1. Scheme of neural network forecasting of regional development [11].

An increase in the use of resources will require, first of all, financial support and labor resources, as a result of these processes there will be an increase in the revenue part of the budget and foreign trade turnover. To assess the reliability of the results obtained, one can use classical statistical and econometric methods.

Neural network technologies will allow solving poorly formalized problems of managing complex dynamic objects when models and algorithms are not adequate to the real state of the controlled process. Neural networks allow us to establish dependencies between indicators of interest (input and output) without explicitly specifying the type of these dependencies. Potential applications of artificial neural networks are viewed in 82 those tasks when, due to uncertainty, for example, due to lack of information, traditional solutions are not effective, and conventional calculations are very laborious.

\section{Analysis and Results}

Innovative development of the region requires the implementation of at least two innovative conditions: the transfer of authority from the national to the regional (local) levels of government and the implementation of tasks to promote and stimulate the development of state, public and private organizations in the region (Gorbachev A.V.\&Starostin A.A., 2004). 
The application of individual measures aimed at improving the process of attracting investment in the region will not give adequate results. We need a systematic management approach to solving the problem on the basis of developing and implementing a state investment policy aimed at restoring the processes of expanded reproduction and targeting the regions to economic selfsufficiency. The strategic goal of state investment policy in modern conditions should be the formation of a mechanism for innovative investment activity through the creation, for example, of regional investment funds that are adequate to the emerging market environment and fit into the emerging and developing market institutions.

A special role in the structure of the organizational and economic management mechanism belongs to regional and municipal governments, since not only the efficiency of the innovation and investment policy developed and implemented, but also the vector of the socioeconomic region as a whole depends on their competence.

In addition, any type of innovation needs government support. In developed countries, specific ways and forms of state support for innovative entrepreneurship have been developed. Within this direction, three broad categories of innovation policy methods can be distinguished: methods of stimulating the supply of innovations (providing financial and technical assistance to innovators, including the creation of a scientific and technical infrastructure); methods of stimulating demand for innovation (government procurement and contracts, especially for new products, processes and services); climate creation methods for innovations (including tax and patent policies and state norms and rules that regulate the state of the economy, the conditions and safety of work and environmental protection) (Tarasenko T.V., 2007).

To ensure the innovative development of the regions, it is necessary to eliminate the above problems with the help of:

creating favorable conditions for the formation of an effective regional innovation infrastructure that would provide financial, informational, consulting, marketing and other types of support for innovation processes;

formation and legislative consolidation of the state policy of innovative development of regions, as well as the development of a program of innovative development of specific regions, taking into account the priority directions of innovation activity;

$>$ introducing new motivational mechanisms of the innovation process, ensuring its commercialization, focusing on meeting market demand.

Thus, the allocated infrastructural, regional and state-management problems impede the innovative development of the regions. Comprehensive implementation of the proposed activities will not only coordinate the activities of regional authorities to implement innovation development programs, but also create a regional innovation infrastructure that organizes and optimizes communication between the subjects of innovation activity and also provides direct participants in the innovation process with the necessary resources as soon as possible. All this will ensure optimal rates of innovation development of the regions, which in turn will increase the efficiency of functioning of both the regional economic system and the entire national economic system as a whole.

\section{Conclusion and recommendations}

The main priorities of innovation development for each region are aimed at creating an effective innovation system in the region, increasing the innovation activity of enterprises and institutions, increasing the share of innovation products and services, innovative renewal of fixed assets, and as a result increasing labor productivity, training personnel for the innovation sphere.

Uzbekistan has a rather high innovation potential, which is determined primarily by a high concentration of educational and research institutions. The infrastructure of innovation begins to form. 
At the same time, the effectiveness of the practical use of the scientific, technical and educational potential of the republic is clearly insufficient, and the formation of the innovation infrastructure is still only at the initial stage. The analysis showed that in recent times there has been a noticeable decline in indicators of innovation activity.

All this testifies to extremely low innovation activity of enterprises, which is due on the one hand to a lack of investment resources, on the other hand to uncertainty in terms of implementation in the market (changing conditions, reducing government orders, etc., the uncertainty of contractual obligations).

Thus, an extremely unfavorable situation in the innovation sphere is emerging, and without a targeted innovation policy it is impossible to overcome the current trends of stagnation and decay. In this regard, the development of an innovative development strategy for the region in the long term, which will contribute to the formation and effective use of the innovation potential, acquires particular relevance.

In this regard, the main task of the regional innovation development strategy is the harmonious and coordinated development of the regional innovation system, providing a full cycle of innovations from the development of innovation to its implementation. This is ensured within the framework of the optimal structure of the regional innovation system.

Thus, the informatization of the economy and society and the strategy of creating a national innovation system, the core of which is the national information system, require an integrated, systematic, program-oriented approach. The information sector of the republic's economy is in a state of development. Information and communication technologies are becoming increasingly important for the formation of information resources and their use in managing the socio-economic development of the republic. In this connection, one of the main directions of the investment development strategy should be the improvement of information technologies for the functioning of government bodies and social institutions.

For short-term forecasting of foreign investment in the region's economy and their further optimal distribution by economic activity in order to provide an additional maximum gross regional product, it is necessary to use a set of mathematical models of neural network modeling and dynamic programming.

\section{References}

1. Decree of the President of the Republic of Uzbekistan "On the strategy of actions for the further development of the Republic of Uzbekistan (February 7, 2017 No. UP-4947)

2. Appendix No. 1 to the Decree of the President of the Republic of Uzbekistan of February 7, 2017 No. UP4947.

3. Tarasenko T.V. Experience in the implementation of government innovation development programs: Monograph / T.V. Tarasenko, S.I. Bishops. - X .: Golden Pages, 2007.

4. Guriev L.K. Conceptual foundations of the innovation strategy of regional development // Science and innovative technologies for regional development: Coll. articles vseros. scientific-practical conf. (June 2003). Penza, 2003. p. 21-23. 2

5. Atoyan V.R., Zhits G.I. Innovative complex of the region: problems of formation and development. Saratov: Sarat. state tech. Univ., 2006. 195 p. five.

6. Osaulenko A.I. Innovation and technology centers as the basis of the innovation and technology policy of the region // Status and ways of development of the economy of the regions of Russia in the 21st century: materials nauch.- practical. conf. (May 26-27, 2003). Tambov, 2003. Part 2. P. 70-77. 7

7. Gorbachev A.V. Starostin A.A. Project management as an effective way to ensure sustainable development of the region // Region in the context of transition to a sustainable model of development of modern Russian society: materials interregion. scientific-practical conf. (Apr. 2004). Bryansk, 2004. Part 1. P. 160-161. eight. 8. Shershnev A.A. The mechanism of formation of regional innovation and investment activities: author. dis. Cand. econ sciences. N. Novgorod, 2004. 29 p.

9. Vysotskaya I.B. State and problems of innovative activity of industry in Ukraine / / Scientific Bulletin of NLTU of Ukraine, 2008

10. Innovation management based on information technologies / O. A. Gorlenko, V. V. Miroshnikov, V. I. Galkin, I. V. Fedorov, A. V. Shevelev. M .: Mashinostroenie-1, 2007. 155 p.

11. Kashintsev N.P. Modeling of regional development based on neural network technologies // Young Scientist. - 2015. - №22. - p. 405-412. - URL https://moluch.ru/archive/102/23011. 
12. Neural networks. Statistica Neural Networks: Translated from English. - M .: Hotline - Telecom, 2000. - 182 p.

13. Stepanova E.N. Neural network forecasting of the socio-economic development of the region [Text] / E.N. Stepanova. - Vologda: VSCC CEMI RAS, 2004. - 104 p.

14. Kashintsev N.P. Neural network modeling of regional development as an instrument of strategic management [Text] / N.P. Kashintsev, R. Yu. Selimenkov // News of the Universities. Series "Economics, finance and production management." 2015. - № 2 (24). - pp. 141-152.

15. Kruglov V.V. Artificial neural networks. Theory and practice [Text] / V.V. Kruglov, V.V. Borisov. - M $\therefore$ Hotline - Telecom, 2001. - 382 p. 